http://jmscr.igmpublication.org/home/ ISSN (e)-2347-176x ISSN (p) 2455-0450

crossref DOI: https://dx.doi.org/10.18535/jmscr/v8i1.126

Journal Of Medical Science And Clinical Research

\title{
Study of Clinical and Haematological Profile of Anaemia in Hospitalised Geriatric Patients
}

\author{
Authors \\ Md. Israrul Haque ${ }^{1}$, Soni Talreja ${ }^{2}$ \\ ${ }^{1}$ Assistant Professor, Department of General Medicine, NSMCH, Bihta, Patna \\ ${ }^{2}$ Assistant Professor, Department of General Medicine, IGIMS, Patna
}

\begin{abstract}
Background: Anemia is an important but under diagnosed cause of morbidity in elderly. The clinical and hematological profile of anemia is different in different geographical area.

Methods: It was a retrospective study. Case files of 100 geriatric patients admitted in Medicine department of IGIMS and NSMCH, Patna with anemia, were selected for the above study. Male patients with $\mathrm{Hb}<13 \mathrm{~g} / \mathrm{dl}$ and female patients with $\mathrm{Hb}<12 \mathrm{~g} / \mathrm{dl}$ were considered in the study. Cases were analyzed to find out clinical and hematological profile of anemia.

Results: The commonest clinical presentation was easy fatigability (70\%), followed by dyspnea (50\%). The commonest cause of anemia was iron deficiency (45\%) followed by Vitamin B 12 and folate deficiency (22\%), anemia of chronic disease (11\%).

Conclusions: Failure to evaluate anemia in elderly lead to delayed diagnosis of potentially treatable conditions. Nonspecific symptoms like fatigue and weakness should not be ignored, presuming that they are part of "normal ageing". An effort should always be made to reach etiological diagnosis before instituting treatment. Role of NSAIDs as a risk factor in anemia should not be overlooked.

Keywords: Anemia of chronic disease, Anemia, Geriatric, Iron deficiency.
\end{abstract}

\section{Introduction}

In recent years there has been a sharp increase in the number of older persons. The UN agreed cut off to refer to Older patients (geriatric age group) is $60+$ years. The world as a whole will have about 435 million additional elderly persons in next 15 years to reach 1.2 billion by 2025 from present 765 million in 2010 (from around $8 \%$ in 2010 to around $12 \%$ in 2025). ${ }^{1}$ According to the Census 2011, India has 104 million older people (60+years), constituting $8.6 \%$ of the total population. $^{2}$

Anemia is common in the elderly and its prevalence increases with age. In elderly person the etiology of anemia differs sufficiently from the etiology of younger adults to warrant considering anemia in geriatric persons as a distinct entity. Using world Health Organization criteria for anemia (Hemoglobin of less than 12gm per dl in woman and less than $13 \mathrm{~g}$ per $\mathrm{dl}$ in men), the prevalence of anemia in the geriatric patients has been found to range from 8 to 44 percent, with the highest prevalence in men 85 years and older. ${ }^{3}$

Anemia is associated with an increased risk for hospitalization and death in community dwelling older adults. Mild anemia was significantly associated with greater mortality in men but not in women. $^{4}$ 
So, it is important to see for the causes and clinical manifestations of anemia in elderly.

\section{Material and Method}

All patients above 60 years of age attending the geriatric clinic in our hospital, over a period of three months, were included in the study to screen for the prevalence of anemia based on WHO criteria of anemia $^{[4]}$ [Hemoglobin $(\mathrm{Hb})<13$ in males, $\mathrm{Hb}<12$ in females]. $\mathrm{A}$ random and nonconsecutive selection of 100 anemic inpatients was done amongst the anemic population to study the pattern of anemia. The following hematological investigations were carried out for all patients- $\mathrm{Hb}$, Total Leucocute Count (TLC), Differential Leucocyte Count (DLC), Erythrocytic Sedimentation Rate (ESR), Platelet count, Blood urea, Serum creatinine, Mean Corpuscular Volume (MCV), Mean Corpuscular Hemoglobin Concentration) MCHC, Mean Corpuscular Hemoglobin (MCH), Packed Cell Volume (PCV), Reticulocyte count, Peripheral smear for blood picture and Serum ferritin. The serum ferritin level is the most effective way to diagnose iron deficiency anemia. When serum ferritin is less than $15 \mathrm{ng} / \mathrm{mL}$, iron deficiency is virtually certain. ${ }^{[5]}$ Iron deficiency is unlikely if ferritin level is greater than $100 \mathrm{ng} / \mathrm{mL}$ (pmol/L). Ferritin levels between 15 and $100 \mathrm{ng} / \mathrm{mL}$ are moderately predictive of iron deficiency anemia.

Vitamin B12 deficiency was defined as serum B12 concentration less than $200 \mathrm{pg} / \mathrm{mL}$. Folate deficiency was defined as serum folate concentration less than $2.6 \mathrm{ng} / \mathrm{mL} .^{[6]}$ Bone marrow studies (aspiration/biopsy) were carried out in patients with blood smear showing immature white cells or nucleated red cells, indeterminate status of iron stores and unexplained progressive or unresponsive anemia. Vitamin B12 and folate assays were done for dimorphic and macrocytic anemia or in patients with normocytic or microcytic blood picture in which no other cause could be found. Additional investigations as indicated for detection of underlying cause-chest X-ray, Ultrasonography
(USG) of abdomen and pelvis, Stool occult blood, Upper Gastrointestinal (GI) endoscopy and colonoscopy, serum electrophoresis, tissue biopsy, imaging-Computed Tomography (CT)/Magnetic Resonance Imaging (MRI), and Anti Nuclear Antibodies (ANA).

\section{Results}

The commonest clinical presentation was easy fatigability $(80 \%)$, followed by dyspnea (50\%). $40 \%$ patients had palpitation at the time of presentation.70 (70\%) patients were males and 30 $(30 \%)$ patients were females.

The mean age of male patients were 66.4 years and females were 69.2 years. Majority of patients belonged to 65-70 years. Commonest type of anemia in our study was Iron deficiency anemia 45patients $(45 \%)$, commonest cause being GI blood loss-32 patients (71\%). Out of 32 patients,22(68\%) patients had upper GI cause for blood loss and 10 (32\%)patients had lower GI cause for blood loss. Among these patients 10 (22\% patients) were on low dose aspirin therapy.

Second commonest type of anemia was megaloblastic anemia secondary to Vit B12 and folate deficiency-20 patients (20\%). 6 patients had Vit B12 deficiency, 4 had folate deficiency, 2 had both Vit B12 and folate deficiency. 8 of these patients had a mixed diet.

Third common type was normocytic normochromic anemia secondary to chronic diseases $(11 \%)$. In patients with anemia of chronic disease, 3 patients had HIV infection (not on zidovudine containing regimen), 4 patients had tuberculosis and 4 patient had CTD.

Hematologic malignancies were presented as anemia in 10 patients. (10\%). 3 cases of chronic myeloid leukemia and one case each of acute myelogenous leukemia, multiple myeloma and non-Hodgkin's lymphoma. cases were 8 CKD patients and 2 cases were newly detected hypothyroid patients. Cause of anemia could not be identified in 4 cases even after thorough evaluation. 


\section{Conclusion}

Failure to evaluate anemia in elderly could lead to delayed diagnosis of potentially treatable conditions. Non specific symptoms like fatigue and weakness should not be ignored in the geriatric population as they could be important pointers towards presence of anemia in these patients. An effort should always be made to reach etiological diagnosis before instituting specific therapy.

\section{Reference}

1. World Health Organization; Definition of an older or elderly person. Available at: http://www.searo.who.int/entity/health_sit uation_tre nds/data/chi/elderlypopulation/en/

2. World Health Organization; Population of elderly person. Available at: http://www.searo.who.int/india/topics/agei ng/en/.

3. Beghe C, Wilson A, Ershler WB. Prevalence and outcome of anemia in geriatrics: systematic review of the literature: Am J Med. 2004;116(suppl 7A):38105.

4. Endres HG, Wedding U, Pittrow D, Thiem U, Trampisch HJ, Diehm C. Prevalence of anemia in elderly patients in primary care: impact on 5-year mortality risk and differences between men and women. Curr Med Res Opin. 2009;25(5):1143-58

5. Elejalde Guerra JI, Alonso Martinez JL, Rubio Vela T, Garcia Labairu C, Llorente B, Echegaray M. Etiological study and diagnosis of anemia in adults over 60 years of age. Sangre.1999;44(6):418-23.

6. Joosten E, Pelemans W, Hiele M, Noyen J. Prevalence and causes of anaemia in a geriatric hospitalized population. Gerontol 1992;38:111-7.

7. Gunter EW, Lewis BG, Koncikowski SM. Laboratory procedures used for the Third National Health and Nutrition Examination Survey (NHANES III),
19881994. Hyattsville, MD: Centers for Disease Control and Prevention; 1996.

8. Mehta BC. Iron deficiency anemia. In Shah SN editor. API Textbook of Kaur et al: Anemia and micronutrient deficiency IJMDS • www.ijmds.org • January 2014; 3(1) 302 Medicine, 7th ed. Association of Physicians of India, Mumbai; 2003.p.9304.

9. Beutler E, Waalen J. The definition of anemia: what is the lower limit of normal of the blood hemoglobin concentration? Blood 2006;107:1747.

10. Chaves PH, Xue QL, Guralnik JM. What constitutes normal hemoglobin concentration in community-dwelling disabled older women? J Am Geriatr Soc 2004; 52:1811. 